\title{
Vietnamese version of the Dual Filial Piety Scale: preliminary validation in a student sample
}

\begin{abstract}
BACKGROUND
Filial piety is a concept containing important ideas about how children should treat their parents. Its demands range from material to emotional requirements, and its structures are often generalized to apply to authority relationships beyond the family. The 16-item Dual Filial Piety Scale (DFPS) developed by Yeh and Bedford has been used in different cultural groups to measure individuals' filial piety attitude. The present investigation translated the DFPS into the Vietnamese language (DFPS-V) and examined psychometric qualities of the scale in a sample of students in Vietnam in two studies.
\end{abstract}

\section{PARTICIPANTS AND PROCEDURE}

In Study 1 we focused on exploratory factor analysis and reliability analysis, using a sample of Vietnamese students $(N=573)$. Study $2(N=300)$ was designed to confirm the factor structure of the scale and provide evidence of validity involving correlates of the resulting survey's scores.
RESULTS

The results confirmed a two-dimensional structure of the scale and indicated satisfactory internal consistency. Additionally, validity of the scale was supported, as it was shown to be associated with positive and negative reciprocity norms.

\section{CONCLUSIONS}

In conclusion, the Vietnamese version of the DFPS has been shown to be a valid and reliable scale that can be used to measure reciprocal and authoritarian filial piety in future studies.

KEY WORDS

dual filial piety model; DFPS-V; Vietnamese scale validation

ORGANIZATION - 1: VNU University of Social Sciences and Humanities, Vietnam National University, Hanoi, Vietnam .

2: Institute of Psychology, University of Gdansk, Gdansk, Poland · 3: Institute of Psychology, Vietnam Academy

of Social Sciences, Hanoi, Vietnam

AUthors' CONTRiButions - A: Study design - B: Data collection - C: Statistical analysis - D: Data interpretation .

E: Manuscript preparation · F: Literature search · G: Funds collection

Corresponding AUthor - Joanna Różycka-Tran, Ph.D., Institute of Psychology, University of Gdansk, 4 Bażyńskiego Str., 80-952 Gdansk, Poland, e-mail: joanna.tran@ug.edu.pl

to Cite this ARTICle - Truong, T. K. H., Różycka-Tran, J., Jurek, P., Tran, H. T., \& Le, V. H. (2020). Vietnamese version of the Dual Filial Piety Scale: preliminary validation in a student sample. Health Psychology Report, 8(3), 263-272.

https://doi.org/10.5114/hpr.2020.95409

RECEIVED 07.01.2020 · REVIEWED 26.03.2020 • ACCEPTED 29.03.2020 • PUBLISHED 14.05.2020 


\section{BACKGROUND}

Filial piety is a quite a modern psychological variable, coming from Asian (mainly Chinese) indigenous psychology. Filial piety refers to "the important virtue and responsibility for the children to respect, care for, and bring honor to their families" (Chen, 2014, p. 308). Filial piety was viewed as a culture-specific concept, embedded in the idea of family interdependence that reflects the close connection between children and their parents (Ho, 1994; Wong, Leung,

Truong Thi

Khanh $\mathrm{Ha}$, Joanna Różycka-Tran, Paweł Jurek, Tran Ha Thu, Le Van Hao \& McBride-Chang, 2010; Yeh \& Bedford, 2003). According to Confucianism ideology, filial piety and filial obligations mean that adult children's behaviors must be respectful and obedient toward their parents (Hwang, 1999). Along with wide dissemination of Confucianism to other countries, filial piety has become a popular notion not only in China, but also in many other Eastern and even Western countries such as Korea (Sung, 1995), Japan (Harris, Long, \& Fujii, 1998), Vietnam (Jamieson, 1993), Thailand and the USA (Sharps, Price-Sharps, \& Hanson, 1998) or lately in Malaysia (Tan, Tan, Nainee, Ong, \& Yeh, 2019). It was the reason that this Confucian virtue appeared to be an ethic, i.e. universal, construct.

Nowadays, filial piety is one of the most basic virtues universally found in diverse cultures throughout human history, influencing leadership and the organizational culture (Low \& Ang, 2012); it not only specifies norms within the family, but also provides the social and ethical foundations for maintaining social order and stable society. In the classic definition, filial piety was a strong belief, or behavior that was morally correct, based on love and respect, referring to children's attitudes about how they should treat their parents (Yeh, 1997). But in modern psychological studies, filial piety is defined as a cognitive script or even a contextualized personality construct for social exchanges in intimate relationships and thus shapes individuals' attitudes (Bedford \& Yeh, 2019).

However, different studies have revealed conflicting findings about whether filial piety is beneficial or harmful (e.g. inhibiting the individual's independence, suppressing creativity, eliminating personal desires and interests) to individual development. The Dual Filial Piety Model (DFPM; Yeh, 2003) integrates these conflicting findings and is composed of two higher-order factors that correspond to the two focal filial piety attributes: reciprocal filial piety (RFP), i.e. need of interpersonal relatedness, and authoritarian filial piety (AFP), i.e. need of social belonging and collective identity, which have been shown to have distinct implications for social adaptation and individuals' psychological functioning (Chen, 2014; Chen, Wu, \& Yeh, 2016; Yeh \& Bedford, 2004; Yeh, Yi, Tsao, \& Wan, 2013). For example, it was found that reciprocal filial piety correlates positively with life satisfaction and social competence of the children, while authoritarian filial piety is negatively associated with self-esteem and social competence (Leung, Wong, Wong, \& McBride-Chang, 2010).

Though the Three-Dimensional Filial Piety Model (TDFPM) as an extension of the DFPM was more recently developed by Shi and Wang (2019), the "DFPM has been the most important theory, and the DFPS (Dual Filial Piety Scale) has been the most widely used scale in current filial piety research thus far" (Shi \& Wang, 2019, p. 2). The DFPM is used to re-conceptualize filial piety from its Chinese culture-specific norms to a contextualized personality construct represented by a pair of culturally sensitive psychological schemas of parent-child interaction, which can provide a platform for research in any culture. Contextualized personality refers to stable patterns of thoughts, feelings, and behaviors that occur within a given context (Bedford \& Yeh, 2019). The DFPM identifies four possible modes of personal interaction with parents, i.e. balanced mode, reciprocal mode, authoritarian mode and non-filial mode (Yeh, 2017): people operating in a balanced mode (high RFP and high AFP) can take personalized practices and role obligations into consideration together; people in the reciprocal mode (high RFP and low AFP) emphasize personal practices over role obligations; people in the authoritarian mode (low RFP and high AFP) have a less intimate and more obedient relationship with their parents; and people functioning in the non-filial mode (low RFP and low AFP) isolate themselves from their parents (Bedford $\&$ Yeh, 2019). These two facets of DFPM (i.e. reciprocal and authoritarian) can be measured by the Dual Filial Piety Scale (DFPS) consisting of 16 items (Yeh, 2003).

\section{DEVELOPMENT AND VALIDATION OF THE ORIGINAL DUAL FILIAL PIETY SCALE (DFPS)}

The first investigations about filial piety scale was based on classic Confucian materials: Yang (1988) postulated fifteen subcategories of meaning concerning filial piety, e.g. tender-heartedness toward parents, obedience to parents or protection of parents. Based on these fifteen subcategories, a scale consisting of fifty-two items was developed, which contains four common factors: respecting and loving parents, supporting and memorializing parents, oppressing oneself, and glorifying parents (Yang, Yeh, \& Huang, 1989). Through confirmatory factor analysis, Yeh (1997) extracted from this scale two distinctive super factors, fundamental values underlying the filial piety concept: reciprocity and authoritarianism, which were explored in further analyses (Yeh, 2003) (Table 1).

Reciprocal filial piety fulfills the psychological need for social and emotional connectedness between two individuals with a horizontal (equal) relationship. The practices of RFP include respecting, caring for, and attending to one's parents. As RFP is motivated 
Table 1

The Dual Filial Piety Model: psychological schemas for interaction with parents

\begin{tabular}{|c|c|c|}
\hline Variable & Reciprocal filial piety (RFP) & Authoritarian filial piety (AFP) \\
\hline $\begin{array}{l}\text { Psychological needs } \\
\text { and manifestations } \\
\text { in different develop- } \\
\text { ment stages }\end{array}$ & $\begin{array}{l}\text { Need for interpersonal relatedness } \\
\text { (toward another individual) } \\
\text { From infancy to adolescence: create } \\
\text { emotional safety and affective bond- } \\
\text { ing with parents (main caregiver) } \\
\text { through expression of love or affection } \\
\text { Adulthood: continuously strengthen } \\
\text { affection and bonding with parents; } \\
\text { understand and support parents' life } \\
\text { needs }\end{array}$ & $\begin{array}{l}\text { Need for collective identity (toward } \\
\text { society or generalized others) } \\
\text { From infancy to adolescence: avoid } \\
\text { punishment and gain social reward } \\
\text { (e.g., parental praise) through learning } \\
\text { to obey parental demands } \\
\text { Adulthood: practice the social role of } \\
\text { child according to common behavioral } \\
\text { standards }\end{array}$ \\
\hline $\begin{array}{l}\text { Features of psycho- } \\
\text { logical functioning }\end{array}$ & $\begin{array}{l}\text { Simultaneously satisfy the mutual } \\
\text { needs (for relatedness and emotional } \\
\text { safety) of parent and child }\end{array}$ & $\begin{array}{l}\text { Consider others' needs (parents, } \\
\text { spouse, or the whole family) before } \\
\text { personal needs }\end{array}$ \\
\hline $\begin{array}{l}\text { Structural features } \\
\text { inherent in the } \\
\text { parent-child } \\
\text { relationship }\end{array}$ & $\begin{array}{l}\text { Equal status between two individuals; } \\
\text { need fulfillment is based on individual } \\
\text { traits or differences }\end{array}$ & $\begin{array}{l}\text { Unequal status between the different } \\
\text { roles within the family hierarchy; need } \\
\text { fulfillment is based on specific role } \\
\text { norms }\end{array}$ \\
\hline
\end{tabular}

Source: Tsao and Yeh, 2019

by gratitude and a desire to repay one's parents for their efforts in raising and caring for their offspring (Yeh et al., 2013), its effects are generally positive; they include better interpersonal relationships and fewer parent-child conflicts (Yeh \& Bedford, 2004) as well as higher life satisfaction (Chen, 2014).

Authoritarian filial piety (AFP) is based on role obligations, submissiveness, and compliance with absolute parental authority, and it fulfills the need for collective identification in a vertical (hierarchical) relationship. Individuals with AFP seek to follow the strict social definition of being a son or a daughter and therefore obey cultural norms and shoulder family responsibilities in order to satisfy parental demands and expectations (Yeh et al., 2013). The effects of AFP are generally more negative, and they include increased levels of depression, anxiety, and aggression (Yeh, 2006); however the cooperativeness and willingness to sacrifice for the family may help to maintain harmony within the family and thus benefit the family as a whole (Yeh \& Bedford, 2004).

What is important, reciprocal and authoritarian factors are not mutually exclusive, but coexist within an individual and may promote the same outcome (Bedford \& Yeh, 2019). Also, both factors can be analyzed on different levels: as individual motives (reciprocal vs. authoritarian) in the context of parentchild relations, the structural properties (horizontal vs. vertical) of the parent-child relationship, social changes in filial norms (core vs. changing aspect) and differences across groups or societies in the expression of individual needs or filial norms (Tsao \& Yeh,
2019). At the cross-cultural level, RFP (representing psychological prototype) and AFP (representing cultural prototype) describe two fundamental psychological schemas that can be identified universally (Yeh, Bedford, \& Yang, 2009).

The aim of the present investigation was to validate a Vietnamese version of the Dual Filial Piety Scale (DFPS) developed by Yeh and Bedford (2003) and involved two studies. In Study 1 we conducted an exploratory factor analysis and reliability analysis, using a sample of Vietnamese students $(N=573)$. Study 2 $(N=300)$ was designed to confirm the two-factor structure of the scale and provide evidence of validity involving correlates of the resulting survey's scores.

\section{VIETNAMESE TRANSLATION OF THE DUAL FILIAL PIETY SCALE}

The authorization of translation of the DFPS was aprroved by the author Kuang-Hui Yeh. The translation followed the recommendations of ITC Guidelines for Translating and Adapting Tests (2017). A back-to-back translation procedure was used, as follows. The original English version of the DFPS was first translated into Vietnamese by a bilingual psychology lecturer. Every effort was made to ensure semantic, idiomatic, and conceptual equivalence, and to preserve overall meaning and nuances. Next, the translated Vietnamese version was back-translated into English without referring to the original English version by another bilingual language expert. Then, both original and 
Truong Thi

Khanh $\mathrm{Ha}$, Joanna Różycka-Tran, Paweł Jurek, Tran Ha Thu, Le Van Hao translated versions of the DFPS were compared in case of any discrepancies. During the translation process, there were two items (number 6 and 8) that we had to reverse in case to make their meaning closer with the original one. We had a problem with translation of item 6: Disregard promises to friends in order to obey my parents [Thất hứa với bạn bè để vâng lời cha mẹ]. In Vietnamese it can be understood that: "my parents want me to disregard promises to friends, so I disregard promises to friends in order to obey my parents". In this case we had to reverse item 6: Obeying my parents even when I have to break my promises to friends [Vâng lời cha mẹ tôi kể cả khi phải thất hứa với bạn bè]. Second, we had the same situation with item 8 : Give up my aspirations to meet my parents' expectations [Từ bỏ nguyện vọng của tôi để đáp ứng mong đợi của cha mẹ]. In Vietnamese it can be understood that "my parents expect that I should (or have to) give up my aspirations, so I give up my aspirations to meet my parents' expectations". So, we also reversed item 8 to Meeting my parents' expectations even when I have to give up my aspirations [Đáp ứng mong đợi của cha mẹ tôi kể cả khi phải từ bỏ nguyện vọng của bản thân]. The rest of the items had a good structure in Vietnamese and did not need to be reversed. Translators resolved discrepancies and agreed on the final wording.

\section{STUDY 1}

\section{PARTICIPANTS AND PROCEDURE}

We collected data from 573 Vietnamese students aged from 18 to 25 years ( $58 \%$ female, $M_{\text {age }}=20.13$, $S D=1.15$ ) who completed a paper-pencil version of the scale. The questionnaire was preceded by demographic information and instruction for everyone. The instruction was "A number of opinions on the social relations with family, other people, and the self are printed below. For each statement, please select (on a scale from 1 - extremely unimportant to me, to 7 - extremely important to me) how important it is to you what the statement describes". The protocol of this study was approved by the Ethics Board for Research Projects at the Institute of Psychology, University of Gdansk. According to the local law of different universities, no written permission from participants was required, as data were collected and analyzed anonymously. Participants were assured that their data would remain anonymous and confidential, as we followed APA standards and the Declaration of Helsinki during data collection.

\section{MEASURES}

Participants filled in the Vietnamese version of the Dual Filial Piety Scale (DFPS-V), which consists of
16 items developed by Yeh and Bedford (2003). Eight items measure reciprocal and another eight items authoritarian filial piety. Respondents indicated how important each statement was to them using a sevenpoint Likert scale ranging from 1 (strongly disagree) to 7 (strongly agree). An example of an item measuring reciprocal filial piety is, "Be grateful to parents for raising you"; the authoritarian items include, "Live with parents even after marriage" (for all scale items and their translation see Table 2).

\section{RESULTS}

An exploratory factor analysis (EFA) was used to identify meaningful factors underlying the Vietnamese version of the DFPS. Conducting EFA we used principal component analysis with varimax rotation. The suitability for analysis was examined by Bartlett's test of sphericity, $\chi^{2}(120)=3147.53, p<.001$, and the Kaiser-Meyer-Olkin measure of sampling adequacy (.87). The number of factors to be retained was guided by Kaiser's criterion (eigenvalues above 1) and consideration for the amount of variance explained by the factor solution, and that two criteria favored the twofactor structure. The solution explained $49 \%$ of the total variance. Two factors resembled those reported by Yeh and Bedford (2003). Factor 1 (31\% of the variance) represents RFP and factor 2 (17\% of the variance) represents AFP. Table 2 presents descriptive statistics for each item and EFA standardized factor loadings.

In the next step, we computed the Cronbach's $\alpha$ internal consistency coefficient to examine the reliability of two filial piety subscales (the EFA result showed the same solution as the initially assumed structure of the measure). Internal consistency reliability was strong for both scores: 88 for the reciprocal filial piety subscale and .84 for the authoritarian filial piety subscale.

We did not find gender differences in our study - women and men had similar mean scores in both subscales, $t(567)=1.57, p=.123$ (for RFP) and $t(567)=1.92, p=.062$ (for AFP). In both groups, the respondents presented clearly higher scores on the RFP subscale $(M=6.20, S D=0.69)$ than on the AFP subscale $(M=3.97, S D=1.10)$. The correlation between the two subscales was slightly positive and statistically significant $(r=.29, p<.01)$.

\section{STUDY 2}

\section{PARTICIPANTS AND PROCEDURE}

We collected data from 300 Vietnamese students (76.7\% female) aged from 18 to 22 years $\left(M_{\text {age }}=19.23\right.$, $S D=1.02)$ who completed a paper-pencil version of the scale. The questionnaire was preceded by demo- 
Table 2

Descriptive statistics and EFA standardized factor loadings for FPS items

\begin{tabular}{|c|c|c|c|c|c|}
\hline & Item & $M$ & $S D$ & Factor 1 & Factor 2 \\
\hline 1 & $\begin{array}{l}\text { Be frequently concerned about my parents' health condi- } \\
\text { tions / Thường xuyên quan tâm đến tình trạng sức khỏe của } \\
\text { cha mẹ tôi }\end{array}$ & 6.43 & 0.97 & .82 & .00 \\
\hline 5 & $\begin{array}{l}\text { Be frequently concerned about my parents' general well- } \\
\text { being / Thường xuyên quan tâm đến sự bình an nói chung } \\
\text { của cha mẹ tôi }\end{array}$ & 6.33 & 0.96 & .75 & .09 \\
\hline 11 & $\begin{array}{l}\text { Be grateful to my parents for raising me / Biết ơn cha mẹ vì } \\
\text { đã nuôi dưỡng tôi }\end{array}$ & 6.59 & 0.86 & .74 & .10 \\
\hline 9 & $\begin{array}{l}\text { Support my parents' livelihood to make their life more com- } \\
\text { fortable / Đỡ đần cha mẹ tôi để làm cho cuộc sống của họ } \\
\text { thoải mái hơn }\end{array}$ & 6.13 & 1.00 & .69 & .12 \\
\hline 7 & $\begin{array}{l}\text { Be concerned about my parents as well as understand them / } \\
\text { Quan tâm đến cha mẹ, và hiểu cha mẹ tôi }\end{array}$ & 5.93 & 1.07 & .69 & .13 \\
\hline 3 & $\begin{array}{l}\text { Talk frequently with my parents to understand their } \\
\text { thoughts and feelings / Thường xuyên nói chuyện với cha mẹ } \\
\text { tôi để hiểu được suy nghĩ và cảm xúc của họ }\end{array}$ & 5.47 & 1.20 & .68 & .12 \\
\hline 15 & $\begin{array}{l}\text { Take the initiative to assist my parents when they are busy / } \\
\text { Chủ động trợ giúp cha mẹ tôi khi họ bận }\end{array}$ & 6.01 & 0.97 & .56 & .29 \\
\hline 13 & $\begin{array}{l}\text { Hurry home upon the death of my parents, regardless of how } \\
\text { far away I am / Nhanh chóng trở về nhà khi biết tin cha mẹ } \\
\text { tôi mất, bất kể tôi ở xa bao nhiêu }\end{array}$ & 6.72 & 0.95 & .53 & .00 \\
\hline 8 & $\begin{array}{l}\text { Give up my aspirations to meet my parents' expectations / } \\
\text { Đáp ứng mong đợi của cha mẹ tôi kể cả khi phải từ bỏ } \\
\text { nguyện vọng của bản thân }\end{array}$ & 3.68 & 1.65 & .04 & .75 \\
\hline 10 & $\begin{array}{l}\text { Do whatever my parents ask right away / Làm bất cú điều gì } \\
\text { cha mẹ tôi yêu cầu ngay lập tức }\end{array}$ & 3.84 & 1.48 & .13 & .71 \\
\hline 6 & $\begin{array}{l}\text { Disregard promises to friends in order to obey my parents / } \\
\text { Vâng lời cha mẹ tôi kể cả khi phải thất hứa với bạn bè }\end{array}$ & 4.62 & 1.34 & .20 & .70 \\
\hline 4 & $\begin{array}{l}\text { Let my income be handled by my parents before marriage / } \\
\text { Để cha mẹ tôi quản lí thu nhập của tôi khi tôi chưa kết hôn }\end{array}$ & 4.02 & 1.62 & .17 & .69 \\
\hline 16 & $\begin{array}{l}\text { Live with my parents (or parents-in-law) when married / Sống } \\
\text { với cha mẹ tôi (hoặc cha mẹ của vợ/chồng) sau khi kết hôn }\end{array}$ & 4.08 & 1.83 & .16 & .67 \\
\hline 12 & $\begin{array}{l}\text { Avoid getting married to someone my parents dislike / Tránh } \\
\text { kết hôn với người mà cha mẹ tôi không thích }\end{array}$ & 3.98 & 1.60 & -.01 & .67 \\
\hline 14 & $\begin{array}{l}\text { Have at least one son for the succession of the family name / } \\
\text { Có ít nhất một con trai để kế thừa dòng dõi gia đình }\end{array}$ & 3.29 & 1.90 & -.06 & .64 \\
\hline 2 & $\begin{array}{l}\text { Take my parents' suggestions even when I do not agree with } \\
\text { them / Nghe theo / làm theo những đề nghị của cha mẹ tôi } \\
\text { ngay cả khi tôi không đồng ý với các đề nghị đó }\end{array}$ & 4.23 & 1.34 & .20 & .60 \\
\hline
\end{tabular}

Note. Extraction method: Principal Component Analysis; Rotation method: Varimax with Kaiser normalization; rotation converged in 3 iterations.

graphic information and instruction for everyone. The ethics standards were applied as in Study 1 . The students were asked to fill out a set of questionnaires consisting of questions regarding personal beliefs about social relations.

\section{MEASURES}

Participants filled in the Vietnamese version of the Dual Filial Piety Scale (DFPS-V), the same as in Study 1 . In addition, they were asked to complete 
Truong Thi

Khanh $\mathrm{Ha}$, Joanna

Różycka-Tran, Paweł Jurek, Tran Ha Thu, Le Van Hao the Positive \& Negative Reciprocity Norm Scale (Eisenberger, Lynch, Aselage, \& Rohdieck, 2004) consisting of 24 items measuring positive and negative reciprocity orientations. According to the scale, individuals with a strong positive reciprocity orientation are expected to be more likely to reward positive behaviors from other individuals (e.g. "I always repay someone who has done me a favour"); on the other hand, individuals with a strong negative reciprocity orientation are thought to be more likely to reciprocate negative acts with negative acts of their own (e.g. "If a person wants to be your enemy, you should treat them like an enemy"). Respondents indicated how important each statement was to them using a seven-point Likert scale ranging from 1 (strongly disagree) to 7 (strongly agree).

\section{RESULTS}

Program R (R Core Team, 2018) and the lavaan package (Rosseel, 2012) were used to conduct confirmatory factor analysis (CFA) using maximum likelihood with robust standard errors (MLM). Two models were tested, including a two-factor model that was proposed by the authors of the original scale, and a onefactor model. Overall model fit was evaluated using the comparative fit index (CFI), Tucker-Lewis index (TLI), and root mean square error of approximation (RMSEA). Although there are no universally accepted metrics of model fit (McDonald, 2010), higher values indicate better fit for the CFI and TLI, whereas lower values indicate better fit for the RMSEA. The following criteria for adequate model fit were adopted: CFI and TLI > .90 and RMSEA < .08 (Kline, 2016). Modelbased reliability was estimated with coefficient omega (McDonald, 1999). CFA results for the Vietnamese version of the Dual Filial Piety Scale are presented in Table 3. These results included a one- and a two-factor model. The two-factor model produced an acceptable solution and was also superior to the one-factor model. Figure 1 presents standardized loadings for the two-factor model. The omega coefficient for the reciprocal filial piety factor was .88 and for the authoritarian filial piety factor was .84 .

The Pearson correlation coefficients were calculated for the results of the DFPS-V, and the Positive
\& Negative Reciprocity Norm Scale. In general, RFP scores correlated moderately with positive reciprocity norm $(r=.34, p<.01)$, but we found no significant correlation with negative reciprocity norm $(r=-.05$, $p=.424)$; whereas AFP slightly positively correlated with both positive $(r=.21, p<.01)$ and negative reciprocity norm $(r=.22, p<.01)$.

\section{DISCUSSION}

Although the filial piety construct comes from Confucian indigenous culture, nowadays the 16-item DFPS is a widely used scale for the measurement of filial piety, in different cultures (e.g. Tan et al., 2019). Despite the very important role of filial piety in Vietnamese society, there was no standardized tool to measure filial piety in Vietnam. So, in the present research, we validated a Vietnamese version of the Dual Filial Piety Scale developed by Yeh and Bedford (2003), testing in two studies its psychometric qualities in two independent samples of students in Vietnam.

In Study 1, an exploratory factor analysis (EFA) was used to identify meaningful factors underlying the Vietnamese version of the DFPS, where two factors resembled those reported by Yeh and Bedford (2003) and internal consistency reliability was strong for both filial piety subscales. In Study 2 confirmatory factor analysis (CFA) was conducted, where two models were tested, including a two-factor model that was proposed by the authors of the original scale, and a one-factor model. As a result, the two-factor model produced an acceptable solution and was also superior to the one-factor model. Both subscales of the DFPS-V have acceptable internal consistency, as reported in the literature (e.g., Yeh \& Bedford, 2003), and correlate slightly positively with each other (Bedford \& Yeh, 2019).

Moreover, the results provide evidence of validity involving correlates of the resulting survey's scores, where RFP correlated moderately with positive but not negative reciprocity norm and AFP slightly positively correlated with both positive and negative reciprocity norm. We must state that we did not find any gender differences in our study - women and men had similar mean scores in both subscales. However, these finding are not consistent with the results of

Table 3

CFA fit statistics for the two structural models of the DFPS-V

\begin{tabular}{lcccccc}
\hline Model & $\chi^{2}$ & $d f$ & CFI & TLI & RMSEA & RMSEA 90\% Cl \\
\hline One-factor & 483.98 & 104 & .57 & .51 & .150 & $.136-.163$ \\
Two-factor & 194.24 & 102 & .92 & .91 & .065 & $.047-.057$ \\
\hline
\end{tabular}

Note. $d f$ - degrees of freedom; CFI - comparative fit index; TLI - Tucker-Lewis index; RMSEA - root mean square error of approximation; $\mathrm{Cl}$ - confidence interval. 


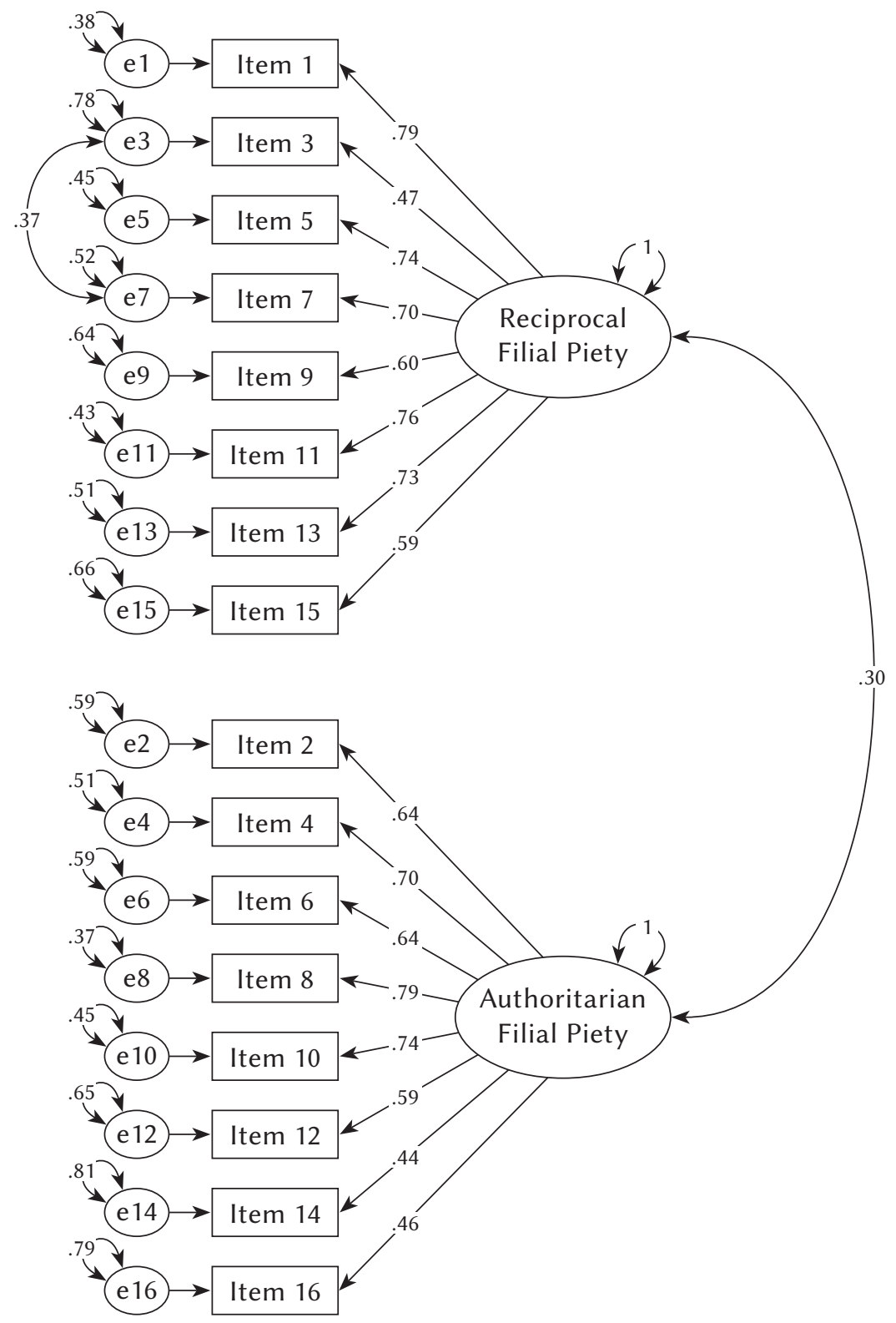

DFPS- $V$

Figure 1. CFA results (standardized loading coefficients) of the DFPS-V.

extant studies of gender differences in filial attitude (e.g. Wong et al., 2010). For example, males tend to provide material and financial support for their parents, while females focus on emotional support and maintaining attachments with family elders (Yue $\& \mathrm{Ng}, 1999)$, and are more likely to be a caregiver for their parents (McGrew, 1998). However, the differences between the current study and previous studies could be derived from the differences between research samples. The majority of Vietnamese students range between 18 and 25 years old. In contemporary Vietnamese society, this period is often considered the "extended adolescence", in which students do not have an income and often receive financial support from their parents instead of supporting their parents' livelihood.
The final conclusion is that the results suggest that filial piety attitude can be explained by two dimensions: reciprocal and authoritarian filial piety (Yeh $\&$ Bedford, 2003). The validated Vietnamese Dual Filial Piety Scale would be a helpful tool for Vietnamese researchers to explore distinct dimensions of filial piety of Vietnamese people, which previously was understood just as a one-positive-dimension structure. In Vietnam, filial piety has been considered the highest moral standard governing intergenerational relationships in families. As Jamieson (1993, p. 16) stated, "first and foremost, (Vietnamese) children were taught filial piety (hiếu), to obey and respect and honor their parents" and "the parent-child relationship was at the very core of Vietnamese culture, dominating everything else". Traditionally, the worst 
Truong Thi

Khanh $\mathrm{Ha}$, Joanna

Różycka-Tran, Paweł Jurek, Tran Ha Thu, Le Van Hao insult which a Vietnamese can receive and by which he is morally and emotionally hurt is the expression "lack of filial piety" (đồ bất hiếu). Filial children are therefore always honoured by family and community and are considered highly ethical. Parents who have brought up good and filial children are evaluated as successful and happy parents. Many Vietnamese proverbs, folk songs, idioms about children's gratitude and filial piety toward their parents have become valuable tools in teaching children up to now. For example, Công cha như núi Thái sơn; nghĩa mẹ nhu nước trong nguồn chảy ra [The debt we owe our father is as great as mount Thái; the debt we owe our mother is as inexhaustible as the streams which flow down from the mountains] or Cá không ăn muối cá ươn; con cương cha me trăm duiờng con hu [The fish which is not preserved (literally does not eat) in salt will be rotten; the child who does not obey his parents will be corrupted in every way]. Thus, filial piety has been an important concept to be examined in order to understand the relationships in the family and organization as family relationships were models for social organization and culture values (RóżyckaTran, Truong, Cieciuch, \& Schwartz, 2017).

However, in contemporary Vietnam, filial piety may have been changed in its level and forms of expression (Nguyen \& Le, 2016; Pham, 2019). Although it is a norm in Vietnam that adult children have to support, look after and obey their aged parents, the expectations of both sides about filial obligations and expectations may be different across generations (Le, 2016). In addition, this study also showed that respect them (elders) was consistently the highest rated item for both young and old participants while obey them (elders) was the lowest rated item. In other words, in expressing filial piety, respect is highly valued but it does not necessarily entail obedience. In the globalized context of industrialization and modernization in the last three decades, young Vietnamese tend to be more individualistic (Do \& Phan, 2002; Le, 2012), more independent and the social foundations for filial piety may have been undermined (Le, 2016). A majority of Vietnamese young people who tend to live in nuclear families rather than extended families have to spend much more time and efforts for improving their expertise, developing their career and raising their own children; they do not have enough time for visiting and helping their parents like parents expect. Often adult children who live far away from their parents or do not have enough time for their parents feel guilty for not being able to take care of their parents well enough. This situation may lead to not only crossgenerational tensions, but also inner conflicts of adult children themselves. The clear distinction of at least two dimensions - reciprocal and authoritarian filial piety - could help to better explain the positive aspects of filial piety and its limitations, to re- duce inner tensions that often occur in the minds of adult children and their parents when judging about the standards of filial piety. The two dimensions of DFPS-V are helpful in examining and understanding the dual (positive and negative) nature of filial piety, and therefore its consequences and relationships with psychological well-being and social functioning should be further explored not only in a rapidly changing Vietnam, but also in cross-cultural comparisons (e.g., Różycka-Tran, Jurek, Truong, Lipowska, \& Olech, 2020).

\section{LIMITATIONS AND FUTURE STUDIES}

Nevertheless, the present study has some limitations. First, it focused solely on the student population, which was inadequate for generalization to the whole nation. Further studies should use a sample with a broader range of ages and occupations including adult children who have both their own children and their aged parents to look after. Second, using a single method (self-report) is not enough. In future studies the construct validity of the DFPS-V should be tested by examining the relationship of filial piety with another validated measurement, and also using another assessment method such as parents' rating. The parents' rating should be compared with the children's rating, because such investigations could reveal the gap between generations which is widening every day. Future studies examining the filial piety indicated by both parents and children's ratings would make a considerable contribution to the knowledge about this important social and psychological concept.

\section{RefERENCES}

Bedford, O., \& Yeh, K. H. (2019). The history and the future of the psychology of filial piety: Chinese norms to contextualized personality construct. Frontiers in Psychology, 10, 100. https://doi. org/10.3389/fpsyg.2019.00100

Chen, W. W. (2014). The relationship between parenting style, filial piety, and life satisfaction in Hong Kong. Journal of Family Psychology, 28, 308-314. https://doi.org/10.1037/a0036819

Chen, W. W., Wu, C. W., \& Yeh, K. H. (2016). How parenting and filial piety influence happiness, parent-child relationships and quality of family life in Taiwanese adult children. Journal of Family Studies, 22, 80-96. https://doi.org/10.1080/13229400. 2015.1027154

Do, L., \& Phan, T. M. H. (Eds.) (2002). Tính cộng đồng, tính cá nhân và cái Tôi của người Việt Nam [Collectivism-individualism and the self of the Vietnamese]. Hanoi: National Political Publishing House. 
Eisenberger, R., Lynch, P., Aselage, J., \& Rohdieck, S. (2004). Who takes the most revenge? Individual differences in negative reciprocity norm endorsement. Personality and Social Psychology Bulletin, 30, 787-799. https://doi.org/10.1177/0146167204264047

Harris, P. B., Long, S. O., \& Fujii, M. (1998). Men and elder care in Japan: a ripple of change? Journal of Cross-Cultural Gerontology, 13, 177-198. https:// doi.org/10.1023/A:1006571508069

Ho, D. Y. F. (1994). Filial piety, authoritarian moralism, and cognitive conservatism in Chinese societies. Genetic, Social and General Psychology Monographs, 120, 349-365.

Hwang, K. K. (1999). Filial piety and loyalty: Two types of social identification in Confucianism. Asian Journal of Social Psychology, 2, 163-183. https://doi.org/10.1111/1467-839X.00031

International Test Commission (2017). The ITC Guidelines for Translating and Adapting Tests (second edition). Retrieved from www.InTestCom.org

Jamieson, N. L. (1993). Understanding Vietnam. Berkeley, CA: University of California Press.

Kline, R. B. (2016). Principles and practice of structural equation modeling (4th ed.). New York: Guilford Press.

Le, V. H. (2012). Các mô thức của tính cá nhân - cộng đồng ở Việt Nam [Patterns of individualism - collectivism in Vietnam]. Journal of Psychology, 11, 13-37.

Le, V. H. (2016). Bổn phận và kỳ vọng về hiếu thảo: Quan điểm của thanh niên và người già ở Hà Nội [Filial obligations and expectations: Current views of young and old people in Hanoi]. Journal of Psychology, 6, 16-28.

Leung, A. N. M., Wong, S. S. F., Wong, I. W. Y., \& McBride-Chang, C. (2010). Filial piety and psychosocial adjustment in Hong Kong Chinese early adolescents. Journal of Early Adolescence, 30, 651-667. https://doi.org/10.1177/0272431609341046

Low, K. C. P., \& Ang, S. L. (2012). Confucian leadership and corporate social responsibility (CSR), the way forward. Asian Journal of Business Research, 2, 85-108.

McDonald, R. P. (2010). Structural models and the art of approximation. Perspectives on Psychological Science, 5,675-686. https://doi.org/10.1177/1745691610388766

McDonald, R. P. (1999). Test theory: a unified treatment. Mahwah, NJ: Erlbaum.

McGrew, K. B. (1998). Daughters' caregiving decisions: From an impulse to a balancing point of care. Journal of Women and Aging, 10, 49-65. https://doi.org/10.1300/J074v10n02_05

Nguyen, T. T., \& Le, C. S. (2016). Biến đổi tích cực của đạo hiếu ở Việt Nam hiện nay [Positive changes of filial piety in Vietnam today]. Khoa học xã hội Việt Nam (Vietnam Social Sciences), 10, 74-77.

Pham, T. K. (2019). Những biến đổi của "đạo hiếu" trong gia đình Việt Nam hiện nay [Changes of filial piety in today Vietnamese families]. Nghiên cứu gia đình và giới (Vietnam Journal of Family and Gender Studies), 2, 37-44.

R Core Team (2018). R: a language and environment for statistical computing. Vienna: R Foundation for Statistical Computing. Retrieved from http://www. R-project.org/.

Rosseel, Y. (2012). lavaan: an R package for structural equation modeling. Journal of Statistical Software, 48, 1-36. https://doi.org/10.18637/jss.v048.i02

Różycka-Tran, J., Truong, T. K. H., Cieciuch, J., \& Schwartz, S. H. (2017). Universals and specifics of the structure and hierarchy of basic human values in Vietnam. Health Psychology Report, 5, 193-204. https://doi.org/10.5114/hpr.2017.65857

Różycka-Tran, J., Jurek, P., Truong, T. K. H., Lipowska, M., \& Olech, M. (2020). The implications of filial piety in study engagement and study satisfaction: Polish-Vietnamese comparison. Frontiers in Psychology (in print).

Sharps, M. J., Price-Sharps, J. L., \& Hanson, J. (1998). Attitudes of young adults toward older adults: Evidence from the United States and Thailand. Educational Gerontology, 24, 655-660. https://doi. org/10.1080/0360127980240703

Shi, J., \& Wang, F. (2019). Three-dimensional Filial Piety Scale: Development and validation of filial piety among Chinese working adults. Frontiers in Psychology, 10, article 2040. https://doi.org/10.3389/ fpsyg.2019.02040

Sung, K. T. (1995). Measures and dimensions of filial piety in Korea. The Gerontologist, 35, 240-247. https://doi.org/10.1093/geront/35.2.240

Tan, C. S., Tan, S. A., Nainee, S., Ong, A. W. H., \& Yeh, K. H. (2019). Psychometric evaluation of the Malay Filial Piety Scale (FPS-M) for adolescents in Malaysia. Journal of Pacific Rim Psychology, 13, e8. https://doi.org/10.1017/prp.2018.29

Tsao, W. C., \& Yeh, K. H. (2019). Indigenous implications and global applications of the dual filial piety model: a psychological re-conceptualization of "Xiao". In K. H. Yeh (Ed.), Asian indigenous psychologies in the global context (pp. 195-219). New York: Palgrave Macmillan.

Wong, S. M., Leung, A. N. M., \& McBride-Chang, C. (2010). Adolescent filial piety as a moderator between perceived maternal control and mother adolescent relationship quality in Hong Kong. Social Development, 19, 187-201. https://doi.org/10.1111/ j.1467-9507.2008.00523.x

Yang, K. S. (1988). Chinese filial piety: a conceptual analysis. In K. S. Yang (Ed.), The Chinese mind (pp. 39-73). Taipei: Laureate Book Company.

Yang, K. S., Yeh, K. H., \& Huang, L. (1989). A social attitudinal analysis of Chinese filial piety: Concepts and assessment. Bulletin of the Institute of Ethnology, 65, 171-227.

Yeh, K. H. (1997). Changes in the Taiwanese people's concept of filial piety. In L. Y. Cheng, Y. H. Lu,

DFPS-V 
Truong Thi

Khanh $\mathrm{Ha}$, Joanna Różycka-Tran, Paweł Jurek, Tran Ha Thu, Le Van Hao
\& F. C. Wang (Eds.), Taiwanese society in the 1990s (pp. 171-214). Taipei: Institute of Sociology/Academia Sinica.

Yeh, K. H. (2003). The beneficial and harmful effects of filial piety: an integrative analysis. In K. S. Yang, K. K. Hwang, P. B. Pedersen, \& I. Daibo (Eds.), Contributions in psychology, no. 42. Progress in Asian social psychology: Conceptual and empirical contributions (pp. 67-82). Westport, CT: Praeger Publishers/ Greenwood Publishing Group.

Yeh, K. H. (2006). The impact of filial piety on the problem behaviours of culturally Chinese adolescents. Journal of Psychology in Chinese Societies, 7, 237-257.

Yeh, K. H. (2017). The whole is greater than the sum of its parts: The integrative potential of the dual framework. In K. H. Yeh (Ed.), The development of Chinese within the context of parent-child interactions (pp. 171-198). Taipei: Wu-Nan Book.

Yeh, K. H., \& Bedford, O. (2003). Filial piety: a test of the Dual Filial Piety model. Asian Journal of Social Psychology, 6, 215-228. https://doi.org/10.1046/ j.1467-839X.2003.00122.x

Yeh, K. H., \& Bedford, O. (2004). Filial belief and parentchild conflict. International Journal of Psychology, 39, 132-144. https://doi.org/10.1080/00207590344000312

Yeh, K. H., Bedford, O., \& Yang, Y.J. (2009). A cross-cultural comparison of coexistence and domain superiority of individuating and relating autonomy. International Journal of Psychology, 44, 213-221. https://doi.org/10.1080/00207590701749146

Yeh, K. H., Yi, C. C., Tsao, W. C., \& Wan, P. S. (2013). Filial piety in contemporary Chinese societies: a comparative study of Taiwan, Hong Kong, and China. International Sociology, 28, 277-296. https://doi.org/ $10.1177 / 0268580913484345$

Yue, X., \& Ng, S. H. (1999). Filial obligations and expectations in China: Current views from young and old people in Beijing. Asian Journal of Social Psychology, 2, 215-226. https://doi.org/10.1111/1467839X.00035 